REVISION 2

\title{
Oxy-dravite, $\mathrm{Na}\left(\mathrm{Al}_{2} \mathrm{Mg}\right)\left(\mathrm{Al}_{5} \mathrm{Mg}\right)\left(\mathrm{Si}_{6} \mathrm{O}_{18}\right)\left(\mathrm{BO}_{3}\right)_{3}(\mathrm{OH})_{3} \mathrm{O}$, a new mineral species of the tourmaline supergroup
}

\author{
FERDINANDO BOSI ${ }^{1}$ AND HENRIK SKOGBY ${ }^{2}$ \\ ${ }^{1}$ Dipartimento di Scienze della Terra, Sapienza Università di Roma, P.le A. Moro, 5, I-00185 Rome, \\ Italy \\ ${ }^{2}$ Department of Mineralogy, Swedish Museum of Natural History, Box 50007, SE-10405 Stockholm, \\ Sweden
}

\section{ABstract} 18

(1)

10

tourmaline supergroup. The holotype specimen originates from the locality of Osarara (Narok district, Kenya) and occurs in quartz-muscovite schist. Crystals of oxy-dravite are dark red, partially translucent with a vitreous luster, a pink streak and conchoidal fracture. It has a Mohs hardness of approximately 7 , and a calculated density of $3.073 \mathrm{~g} / \mathrm{cm}^{3}$. In plane polarized light, oxy-dravite is pleochroic $(\mathrm{O}=$ orange and $\mathrm{E}=$ pink $)$ and uniaxial negative: $\omega=1.650(5), \varepsilon=$ 1.620(5). Oxy-dravite is rhombohedral, space group $R 3 m$, with the unit-cell parameters $a=$ 15.9273(2) and $c=7.2001(1) \AA, V=1581.81(4) \AA^{3}, Z=3$. Chemical characterization based on electron microprobe analysis, single-crystal structure refinement, Mössbauer and optical spectroscopy, resulted in the unit formula:

$$
\begin{aligned}
& \mathrm{X}_{\left(\mathrm{Na}_{0.83} \square_{0.15} \mathrm{~K}_{0.02}\right)_{\Sigma 1.00}{ }^{\mathrm{Y}}\left(\mathrm{Al}_{1.34} \mathrm{Fe}^{3+}{ }_{0.58} \mathrm{Mg}_{1.03} \mathrm{Fe}^{2+}{ }_{0.03} \mathrm{Ti}_{0.02}\right)_{\Sigma 3.00}{ }^{\mathrm{Z}}\left(\mathrm{Al}_{4.95} \mathrm{Mg}_{1.03} \mathrm{Fe}^{3+}{ }_{0.02}\right)_{\Sigma 6.00}}{ }^{\mathrm{T}}\left(\mathrm{Si}_{5.98} \mathrm{Al}_{0.02} \mathrm{O}_{18}\right)_{\Sigma 6.00}{ }^{\mathrm{B}}\left(\mathrm{BO}_{3}\right)_{3}{ }^{\mathrm{V}}(\mathrm{OH})_{3}{ }^{\mathrm{W}}\left(\mathrm{O}_{0.76} \mathrm{OH}_{0.24}\right)_{\Sigma 1.00} .
\end{aligned}
$$

While the end-member formula of oxy-dravite may be formalized as $\mathrm{Na}^{\mathrm{Y}}\left(\mathrm{Al}_{3}\right)^{\mathrm{Z}}\left(\mathrm{Al}_{4} \mathrm{Mg}_{2}\right) \mathrm{Si}_{6} \mathrm{O}_{18}\left(\mathrm{BO}_{3}\right)_{3}(\mathrm{OH})_{3} \mathrm{O}$, the most representative ideal structural formula is 
$33 \mathrm{Na}^{\mathrm{Y}}\left(\mathrm{Al}_{2} \mathrm{Mg}\right)^{\mathrm{Z}}\left(\mathrm{Al}_{5} \mathrm{Mg}\right) \mathrm{Si}_{6} \mathrm{O}_{18}\left(\mathrm{BO}_{3}\right)_{3}(\mathrm{OH})_{3} \mathrm{O}$. The difference between these two formulae is 34 solely in Al-Mg order-disorder, i.e., there is no difference in chemical composition. Although the $\mathrm{Mg}$-Al disorder over the $Y$ and $Z$ sites is controlled by the short-range bond-valence requirements of $\mathrm{O}^{2-}$ at the $\mathrm{O} 1(\equiv \mathrm{W})$ site, the amount of $\mathrm{Mg}$ at the $Z$ site is a function of the degree of cation size mismatch at $\mathrm{Z}$.

The crystal structure of oxy-dravite was refined to statistical index $R 1$ of $1.17 \%$ using 1586 equivalent reflections collected with $\mathrm{MoK \alpha} \mathrm{X}$-radiation. Oxy-dravite is chemically related to dravite (and fluor-dravite), $\mathrm{NaMg}_{3} \mathrm{Al}_{6} \mathrm{Si}_{6} \mathrm{O}_{18}\left(\mathrm{BO}_{3}\right)_{3}(\mathrm{OH})_{3}(\mathrm{OH}, \mathrm{F})$, by the heterovalent substitution $\mathrm{Al}^{3+}+\mathrm{O}^{2-} \rightarrow \mathrm{Mg}^{2+}+(\mathrm{OH}, \mathrm{F})^{1-}$.

\section{INTRODUCTION}

The tourmaline supergroup minerals are widespread, occurring in a wide variety of sedimentary, igneous and metamorphic rocks. They are known as valuable indicator minerals that can provide information on the compositional evolution of their host rocks, chiefly due to their ability to incorporate a large number of elements (e.g., Novák et al. 2004; Agrosì et al. 2006; Lussier et al. 2011a; Novák et al. 2011; van Hinsberg et al. 2011). However, the chemical composition of tourmalines is also strongly controlled by various crystal-structural constraints (e.g., Hawthorne 1996, 2002a; Bosi 2010, 2011; Henry and Dutrow 2011; Skogby et al. 2012) as well as by temperature (e.g., van Hinsberg and Schumacher 2011). Tourmaline supergroup minerals are complex borosilicates and their crystal structure and crystal chemistry have been widely studied (e.g., Foit 1989; Hawthorne and Henry 1999; Bosi and Lucchesi 2007; Lussier et al. 2008; Bosi et al. 2010; Lussier et al. 2011b). In accordance with Henry et al. (2011), the general formula of tourmaline may be written as: $\mathrm{XY}_{3} \mathrm{Z}_{6} \mathrm{~T}_{6} \mathrm{O}_{18}\left(\mathrm{BO}_{3}\right)_{3} \mathrm{~V}_{3} \mathrm{~W}$, where $\mathrm{X}\left({ }^{[9]} X\right)=\mathrm{Na}^{+}, \mathrm{K}^{+}, \mathrm{Ca}^{2+}, \square(=$ vacancy $) ; \mathrm{Y}\left(\equiv{ }^{[6]} Y\right)=\mathrm{Al}^{3+}, \mathrm{Fe}^{3+}, \mathrm{Cr}^{3+}, \mathrm{V}^{3+}, \mathrm{Mg}^{2+}, \mathrm{Fe}^{2+}$, $\mathrm{Mn}^{2+}, \mathrm{Li}^{+} ; \mathrm{Z}\left({ }^{[6]} \mathrm{Z}\right)=\mathrm{Al}^{3+}, \mathrm{Fe}^{3+}, \mathrm{Cr}^{3+}, \mathrm{V}^{3+}, \mathrm{Mg}^{2+}, \mathrm{Fe}^{2+} ; \mathrm{T}\left({ }^{[4]} \mathrm{T}\right)=\mathrm{Si}^{4+}, \mathrm{Al}^{3+}, \mathrm{B}^{3+} ; \mathrm{B}\left(\equiv{ }^{[3]} \mathrm{B}\right)=$ $\mathrm{B}^{3+} ; \mathrm{W}\left(\equiv{ }^{[3]} \mathrm{O} 1\right)=\mathrm{OH}^{1-}, \mathrm{F}^{1-}, \mathrm{O}^{2-} ; \mathrm{V}\left(\equiv{ }^{[3]} \mathrm{O} 3\right)=\mathrm{OH}^{1-}, \mathrm{O}^{2-}$ and where, for example, $\mathrm{T}$

61 represents a group of cations $\left(\mathrm{Si}^{4+}, \mathrm{Al}^{3+}, \mathrm{B}^{3+}\right)$ accommodated at the [4]-coordinated $T$ sites.

62 The dominance of these ions at one or more sites of the structure gives rise to a range of 63 distinct mineral species (Henry et al. 2011). 


$$
\mathrm{Na}^{\mathrm{Y}}\left(\mathrm{Al}_{2} \mathrm{Mg}\right)^{\mathrm{Z}}\left(\mathrm{Al}_{5} \mathrm{Mg}\right) \mathrm{Si}_{6} \mathrm{O}_{18}\left(\mathrm{BO}_{3}\right)_{3}(\mathrm{OH})_{3} \mathrm{O}
$$

67 Successively the name was confirmed in the approved classification scheme of Henry et al.

68 (2011), but with a new ideal formula:

$$
\mathrm{Na}^{\mathrm{Y}}\left(\mathrm{Al}_{3}\right)^{\mathrm{Z}}\left(\mathrm{Al}_{4} \mathrm{Mg}_{2}\right) \mathrm{Si}_{6} \mathrm{O}_{18}\left(\mathrm{BO}_{3}\right)_{3}(\mathrm{OH})_{3} \mathrm{O}
$$

Although these two structural formulas are chemically equivalent, formula (1) shows a disordering of $\mathrm{Mg}$ over the $Y$ and $Z$ sites, whereas formula (2) shows an ordering of $\mathrm{Mg}$ at the $Z$ site. As these two structural formulae show long-range disordered (1) and long-range ordered site populations (2) for the bulk composition $\mathrm{NaMg}_{2} \mathrm{Al}_{7} \mathrm{Si}_{6} \mathrm{O}_{18}\left(\mathrm{BO}_{3}\right)_{3}(\mathrm{OH})_{3} \mathrm{O}$, we define (1) as the disordered formula and (2) as the ordered formula. The name oxy-dravite has been previously used for some time in the literature despite the lack of a formal definition of the mineral (e.g., Žàček et al. 2000; Novák et al. 2004; Bosi et al. 2010).

The new species as well as the name have been approved by the Commission on New (IMA 2012-004a). The holotype specimen of oxy-dravite is deposited in the collections of the Museum of Mineralogy, Earth Sciences Department, Sapienza University of Rome, Italy, catalogue number 33066. A formal description of the new species oxy-dravite is presented here, including a full characterization of its physical, chemical and structural attributes. and occurs in quartz-muscovite schist (Dunn et al. 1975). The crystal is inclusion-free and occurs as an euhedral crystal approximately $7 \times 7 \times 15 \mathrm{~mm}$ in size. It is dark red in color, with pink streak, partially translucent and has a vitreous luster (Fig. 1). It is brittle and shows conchoidal fracture. The Mohs hardness is approximately 7 and the calculated density is 3.073 $\mathrm{g} / \mathrm{cm}^{3}$. In transmitted light, oxy-dravite is pleochroic with $\mathrm{O}=$ orange and $\mathrm{E}=$ pink. Oxydravite is uniaxial negative with refractive indices, measured by the immersion method using white light from a tungsten source, of $\omega=1.650(5), \varepsilon=1.620(5)$. The mean index of 
It is worth pointing out that the dark red bulk color as well as the pleochroism observed is most likely caused by relatively minor concentrations of $\mathrm{Fe}^{3+}$ present in the mineral (Taran and Rossman 2002).

\section{Single-crystal structural refinement (SREF)}

A representative fragment of the type specimen was selected for X-ray diffraction measurements on a Bruker KAPPA APEX-II single-crystal diffractometer, at Sapienza University of Rome (Earth Sciences Department), equipped with a CCD area detector $(6.2 \times$ $6.2 \mathrm{~cm}^{2}$ active detection area, $512 \times 512$ pixels) and a graphite crystal monochromator, using $\mathrm{MoK} \alpha$ radiation from a fine-focus sealed X-ray tube. The sample-to-detector distance was 4 $\mathrm{cm}$. A total of 3265 exposures $\left(\mathrm{step}=0.2^{\circ}\right.$, time $/ \mathrm{step}=20 \mathrm{~s}$ ) covering the full reciprocal sphere with a high redundancy of about 8 was used. Final unit-cell parameters were refined by means of the Bruker AXS SAINT program using reflections with $I>10 \sigma(I)$ in the range $8^{\circ}<$ $2 \theta<69^{\circ}$. The intensity data were processed and corrected for Lorentz, polarization, and background effects with the APEX2 software program of Bruker AXS. The data were corrected for absorption using the multi-scan method (SADABS). The absorption correction led to a significant improvement in $R_{\text {int }}$ (from 0.0363 to 00266). No violations of $R 3 \mathrm{~m}$ symmetry were noted.

Structural refinement was carried out with the SHELXL-97 program (Sheldrick 2008). Starting coordinates were taken from Bosi and Lucchesi (2004). Variable parameters that were refined include: scale factor, extinction coefficient, atomic coordinates, site scattering values and atomic displacement factors. To obtain the best values of statistical indexes $(R 1, w R 2)$, a fully ionized $\mathrm{O}$ scattering curve was used, whereas neutral scattering curves were used for the other atoms. In detail, the $X$ site was modeled using Na scattering factors. The occupancy of the $Y$ site was obtained considering the presence of $\mathrm{Al}$ vs. Fe. The $Z, T$ and $B$ sites were modeled, respectively, with $\mathrm{Al}, \mathrm{Si}$ and B scattering factors and with a fixed occupancy of 1 , because refinement with unconstrained occupancies showed no significant deviations from this value. Three full-matrix refinement cycles with isotropic displacement parameters for all atoms were followed by anisotropic cycles until convergence was attained. No significant correlations over a value of 0.7 between the parameters were observed at the end of 
This is a preprint, the final version is subject to change, of the American Mineralogist (MSA)

Cite as Authors (Year) Title. American Mineralogist, in press.

(DOI will not work until issue is live.) DOI: http://dx.doi.org/10.2138/am.2014.4441

130 refinement. Table 1 lists crystal data, data collection information and refinement details; Table

1312 gives the fractional atomic coordinates and site occupancies; Table 3 gives the displacement

132 parameters; Table 4 gives selected bond distances.

133

$X$-ray powder diffraction

135 The X-ray powder-diffraction pattern for the oxy-dravite sample was collected using a

136 Panalytical X'pert powder diffractometer equipped with an X'celerator silicon-strip detector.

137 The range $5-80^{\circ}(2 \theta)$ was scanned with a step-size of $0.017^{\circ}$ during 30 minutes using a sample

138 spinner with the sample mounted on a background-free holder. The diffraction data (in $\AA$ for

$139 \mathrm{CuK}, \lambda_{1}=1.54060 \AA$ ), corrected using Si as an internal standard, are listed in Table 5. Unit-

140 cell parameters from the powder data were refined using the program UnitCell (Holland and

141 Redfern 1997): $a=15.919(1) \AA, c=7.200(1) \AA, V=1580.3(1) \AA^{3}$.

\section{Electron Microprobe analysis (EMPA)}

144 Electron microprobe analyses of the crystal used for X-ray diffraction refinements were

145 obtained by using wavelength-dispersive spectrometry with a Cameca SX50 instrument at the

146 "Istituto di Geologia Ambientale e Geoingegneria (Rome, Italy), CNR", operating at an 147 accelerating potential of $15 \mathrm{kV}$ and a sample current of $15 \mathrm{nA}$ ( $5 \mu \mathrm{m}$ beam diameter). Minerals 148 and synthetic compounds were used as standards: wollastonite ( $\mathrm{SiK \alpha}, \mathrm{CaK \alpha})$, magnetite $149(\mathrm{Fe} K \alpha)$, rutile $(\mathrm{Ti} K \alpha)$, corundum $(\mathrm{Al} K \alpha)$, fluorphlogopite $(\mathrm{F} K \alpha)$, periclase $(\mathrm{Mg} K \alpha)$, jadeite $150(\mathrm{NaK} \alpha), \mathrm{K}$-feldspar $(\mathrm{K} K \alpha)$, sphalerite $(\mathrm{ZnK} \alpha)$, along with metallic $\mathrm{Cr}, \mathrm{V}, \mathrm{Mn}$ and $\mathrm{Cu}$. The 151 PAP matrix correction procedure (Pouchou and Pichoir 1991) was applied to reduce the raw 152 data. The results, which are summarized in Table 5, represent mean values of 10 spot analyses.

153 In accordance with the documented very low concentration of $\mathrm{Li}$ in dravitic samples (e.g., 154 Henry et al. 2011), the $\mathrm{Li}_{2} \mathrm{O}$ content was assumed to be insignificant. Manganese, $\mathrm{Cr}, \mathrm{V}, \mathrm{Zn}$, $155 \mathrm{Cu}, \mathrm{Ca}$ and $\mathrm{F}$ were found to be below their respective detection limits varying between 0.03 156 wt. $\%$ and 0.05 wt. $\%$.

\section{Mössbauer spectroscopy (MS)}

159 The oxidation state of Fe was determined by Mössbauer spectroscopy at room 160 temperature using a conventional spectrometer system operating in constant-acceleration 161 mode. In order to spare the holotype material, the absorber was prepared by filling a small 
162 quantity of ground material in a 1-mm hole in a lead plate, and the spectrum then acquired

163 using a closely positioned ${ }^{57}$ Co point-source in rhodium matrix with a nominal activity of 10

$164 \mathrm{mCi}$. The spectrum was calibrated against $\alpha$-Fe foil and folded before fitting using the MDA

165 software by Jernberg and Sundqvist (1983). The resultant spectrum (Fig. 2) shows a relatively

166 broad central absorption doublet with weak shoulder features. On a sample of similar

167 composition from Osarara, Narok district, Kenya (NMNH\#126030), Mattson and Rossman

168 (1984) obtained a comparable spectrum and interpreted the broad bands as being caused by

169 relaxation effects. The spectrum of the holotype specimen was fitted with two bands assigned

170 to $\mathrm{Fe}^{3+}$ and one band assigned to $\mathrm{Fe}^{2+}$, resulting in an $\mathrm{Fe}^{3+} / \Sigma \mathrm{Fe}$ ratio of approximately 0.96 .

\section{Optical spectroscopy (OAS)}

Polarized room temperature optical absorption spectra in the $\varepsilon$ and $\omega$ directions were recorded on a $31 \mu \mathrm{m}$ thick crystal section in the UV/VIS to NIR spectral range (330-1500 nm) with a Zeiss MPM800 microscope spectrometer (cf. Halenius et al. 2011). The obtained spectra (not shown here) are very similar to those reported by Mattson and Rossman (1984) and Taran and Rossman (2002) for the NMNH\#126030 sample, showing three absorption bands at 486, 540 and $545 \mathrm{~nm}$ related to $\mathrm{Fe}^{3+}-\mathrm{Fe}^{3+}$ pair transitions and two $\mathrm{Fe}^{2+}$ bands around 700 and $1100 \mathrm{~nm}$ (Taran and Rossman 2002).

\section{RESULTS}

\section{Determination of atomic proportions}

In agreement with the structural refinement results, the boron content was assumed to be stoichiometric in the sample of oxy-dravite $(B=3.00$ atoms per formula unit, apfu). In fact, both the site-scattering results and the bond lengths of $B$ and $T$ are consistent with the $B$ site fully occupied by boron, but along with it being absent at the $T$ site. The $\mathrm{OH}$ content can then be calculated by charge balance with the assumption $(T+Y+Z)=15.00$. The atomic proportions were calculated on this assumption (Table 5). The excellent match between the number of electrons per formula unit (epfu) derived from chemical and structural analysis supports this procedure: 231.8 epfu vs. 232.8 epfu, respectively. 


\section{Site populations}

195 Anion site populations were apportioned following the protocols of Grice and Ercit

196 (1993) and Henry et al. (2011): the O3 site (V position in the general formula) is occupied by

$197 \mathrm{OH}$ and $\mathrm{O}^{2-}$, while the $\mathrm{O} 1$ site (W position in the general formula) is occupied by $\mathrm{O}^{2-}$ and $\mathrm{OH}$.

198 The cation distribution at the $T, Y$ and $Z$ sites was optimized by using a quadratic program (for

199 details, see Bosi and Lucchesi 2004) to minimize the residuals between calculated and

200 observed data (based on the chemical and structural analysis). Site scattering values,

201 octahedral and tetrahedral mean bond distances (i.e., $<Y-\mathrm{O}>,<\mathrm{Z}-\mathrm{O}>$ and $<\mathrm{T}-\mathrm{O}>$ ) were

202 calculated as the linear contribution of each cation multiplied by its specific bond distance

203 (Table 6). More details about the specific distances derived from the ionic radii are found in

204 Bosi and Lucchesi (2007). The robustness of this approach was confirmed by another

205 optimization procedure (Wright et al. 2000) which led to very similar cation distributions in

206 the present sample (Table 6). This result represents another example of convergence of these

207 two procedures to similar solutions for tourmaline (i.e., Bosi and Lucchesi 2007; Filip et al.

208 2012; Bosi et al. 2012; Bosi et al. 2013).

209 The empirical structural formula of oxy-dravite is:

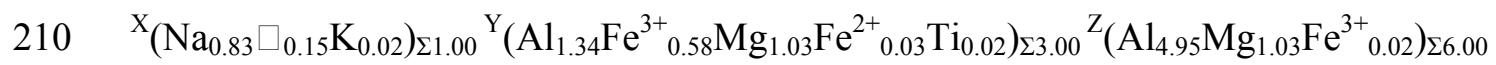

$211{ }^{\mathrm{T}}\left(\mathrm{Si}_{5.98} \mathrm{Al}_{0.02} \mathrm{O}_{18}\right)_{\Sigma 6.00}{ }^{\mathrm{B}}\left(\mathrm{BO}_{3}\right)_{3}{ }^{\mathrm{V}}(\mathrm{OH})_{3}{ }^{\mathrm{W}}\left(\mathrm{O}_{0.76} \mathrm{OH}_{0.24}\right)_{\Sigma 1.00}$.

212 The results from bond-valence analysis are also consistent with the proposed structural

213 formula. Bond valence calculations, using the formula and bond-valence parameters from

214 Brown and Altermatt (1985), are reported in Table 7. In particular, note that the value of bond

215 valence sum incident at the $\mathrm{O} 1$ site (1.53 valence units) implies that $\mathrm{O} 1(\equiv \mathrm{W})$ is only partially

216 occupied by an $\mathrm{OH}$ group (expected value close to 1). This is consistent with $\mathrm{O}^{2-}$ being

217 dominant at the $\mathrm{O} 1$ site (expected value close to 2). This finding can be verified by means of

218 the empirical relation reported in the CNMNC-approved proposal IMA 2012-004a by Bosi

219 and Skogby, in which the $\mathrm{OH}$ content at $\mathrm{O} 1$ in tourmaline can be estimated by considering the

220 bond valence sum at $\mathrm{O} 1$ and the $\mathrm{F}$ content according to: ${ }^{\mathrm{W}} \mathrm{OH}=[2-\mathrm{BVS}(\mathrm{O} 1)-0.20-\mathrm{F}]$.

221 The resulting value $(0.27 \mathrm{apfu})$ is very close to the $\mathrm{OH}$ value obtained by stoichiometry $(0.24$

$222 \mathrm{apfu})$. It is noteworthy that the very small amounts of $\mathrm{Fe}^{3+}$ at the $Z$ site (0.02 apfu) optimized

223 in the structural formula are in good agreement with the presence of $\mathrm{Fe}^{3+}$ at $Z$ observed in the

224 polarized optical absorption spectrum of oxy-dravite samples from Osarara, with a band at 540 
225

226

227

228

229

230

231

232

233

234

235

236

237

238

239

240

241

242

243

244

245

246

247

248

249

250

251

252

253

254

255

256

$\mathrm{nm}$ ( $\mathbf{E}$ parallel to the $\mathbf{C}$ axis) assigned to electronic ${ }^{\mathrm{Z}} \mathrm{Fe}^{3+}-{ }^{\mathrm{Z}} \mathrm{Fe}^{3+}$ pair transitions (Mattson and Rossman 1984; Taran and Rossman 2002).

\section{Red tourmalines}

Although not previously classified as oxy-dravite, unusual red $\mathrm{Fe}^{3+}$-rich tourmalines from Osarara (Narok district, Kenya) have been previously studied by different techniques, in order to define the chemistry, the structure and the interactions between and among ions in the atomic sites (Dunn et al. 1975, EMPA; Mattson and Rossman 1984, EMPA, MS and OAS; Hawthorne et al. 1993, EMPA and SREF; Taran and Rossmann 2002, OAS). However, some differences occur with respect to the data obtained for the holotype specimen: for example, the unit-cell parameters are $a=15.9273(2)$ and $c=7.2001(1) \AA$ in our sample, and $a=15.947(2)$ and $c=7.214(1) \AA$ in Hawthorne et al. (1993). Moreover, although the structural formula reported by Hawthorne et al. (1993) shows a cation site populations quite similar to that of our sample, the anion site populations at $\mathrm{O} 3$ and $\mathrm{O} 1$ were not specified, since the atomic proportions were calculated by the assumption ${ }^{\mathrm{V}+\mathrm{W}}(\mathrm{OH}+\mathrm{F})=4.00$ apfu, instead of the more appropriate assumption $(T+Y+Z)=15.00$ apfu. The latter assumption implies: 1) no vacancies at the octahedrally-coordinated sites in line with the crystal structure information and 2) a site population at $\mathrm{O} 1$ in line with the bond-valence sum value incident at the $\mathrm{O} 1$ site ( $\sim 1.5$ valence units). As a result, the anion population is ${ }^{\mathrm{W}}\left(\mathrm{O}_{0.69} \mathrm{OH}_{0.31}\right)$. It is noteworthy that the anion population is consistent with the short-range bond-valence constrains around $\mathrm{O} 1$, thus implying that the $\mathrm{Mg}$-Al disorder over the $Y$ and $Z$ sites should be coupled to the incorporation of $\mathrm{O}^{2-}$ at the $\mathrm{O} 1$ site (e.g., Taylor et al. 1995; Hawthorne 1996).

\section{Nomenclature}

The empirical structural formula of the sample examined in this study indicates this tourmaline-supergroup mineral is best classed in the alkali group, oxy-subgroup 3 (Henry et al. 2011) with $\mathrm{Na}$ dominant at the $\mathrm{X}$ position of the general formula, oxygen dominant at the $\mathrm{W}$ position with $\mathrm{O}^{2-}>\mathrm{OH}$, and $\mathrm{Al}$ as the dominant cation at the $\mathrm{Y}$ and $\mathrm{Z}$ positions. Disregarding the minor constituents $\left(\mathrm{K}, \mathrm{Fe}^{2+}\right.$ and $\mathrm{Ti}$ and $\left.{ }^{\mathrm{T}} \mathrm{Al}\right)$ and replacing $\left(+\mathrm{OH}^{-}\right)$by $\left(\mathrm{Na}^{+}+\mathrm{O}^{2-}\right)$ and 
$\mathrm{Fe}^{3+}$ by $\mathrm{Al}$, the empirical structural formula of the studied tourmaline can be approximated as $\mathrm{Na}^{\mathrm{Y}}\left(\mathrm{Al}_{2} \mathrm{Mg}\right)^{\mathrm{Z}}\left(\mathrm{Al}_{5} \mathrm{Mg}\right) \mathrm{Si}_{6} \mathrm{O}_{18}\left(\mathrm{BO}_{3}\right)_{3}(\mathrm{OH})_{3} \mathrm{O}$, that is, one having a disordered formula (1). As this composition has multiple cations at more than one site (i.e., $\mathrm{Al}$ and $\mathrm{Mg}$ ), it is not in accordance with the characteristics of an ordered end-member formula as defined by Hawthorne (2002b).

\section{End-member formula}

The empirical formula presented above can be rearranged to the two possible end-

$\mathrm{Na}^{\mathrm{Y}}\left(\mathrm{Al}_{3}\right)^{\mathrm{Z}}\left(\mathrm{Al}_{4} \mathrm{Mg}_{2}\right) \mathrm{Si}_{6} \mathrm{O}_{18}\left(\mathrm{BO}_{3}\right)_{3}(\mathrm{OH})_{3} \mathrm{O}$.

In accordance with the short-range bond-valence requirements at O1 (e.g., Hawthorne 1996), however, the end-member with $\mathrm{Mg}$ ordered at $\mathrm{Y}$ would suggest the existence of an unstable short-range arrangement ${ }^{\mathrm{Y}}(\mathrm{Al}+2 \mathrm{Mg})-{ }^{\mathrm{W}}\left(\mathrm{O}^{2-}\right)$ in oxy-dravite, whereas the endmember with $\mathrm{Mg}$ ordered at $\mathrm{Z}$ is both consistent with the occurrence of the stable short-range arrangement ${ }^{\mathrm{Y}}(3 \mathrm{Al})-{ }^{\mathrm{W}}\left(\mathrm{O}^{2-}\right)$ and with the characteristics of an end-member composition (Hawthorne 2002b). Consequently, the $\mathrm{Na}^{\mathrm{Y}}\left(\mathrm{Al}_{3}\right)^{\mathrm{Z}}\left(\mathrm{Al}_{4} \mathrm{Mg}_{2}\right) \mathrm{Si}_{6} \mathrm{O}_{18}\left(\mathrm{BO}_{3}\right)_{3}(\mathrm{OH})_{3} \mathrm{O}$ formula is preferred as the end-member oxy-dravite composition. Finally, note that both the disordered formula (1) and the empirical formula are consistent with the stable short-range arrangement ${ }^{\mathrm{Y}}(2 \mathrm{Al}+\mathrm{Mg})-^{\mathrm{W}}\left(\mathrm{O}^{2-}\right)$ (Hawthorne 1996).

\section{Name and relation to other species}

By analogy to the relationship between oxy-schorl and schorl (Bačík et al. 2013), oxychromium-dravite and chromium-dravite (Bosi et al. 2012), oxy-vanadium-dravite and "vanadium-dravite" (Bosi et al. 2013), the name oxy-dravite is given in relation to dravite. The prefix oxy represents the heterovalent substitution $\mathrm{Al}^{3+}+\mathrm{O}^{2-} \rightarrow \mathrm{Mg}^{2+}+(\mathrm{OH})^{1-}$ relative to the root composition of dravite. Replacing $(\mathrm{OH})$ by $\mathrm{F}$ in the above heterovalent substitution, also suggests a relationship between oxy-dravite and fluor-dravite, the latter being the fluorequivalent of dravite (Clark et al. 2011). Comparative data for oxy-dravite, fluor-dravite and dravite are given in Table 8. Ideally, oxy-dravite is related to oxy-schorl, oxy-chromiumdravite, oxy-vanadium-dravite and povondraite through the homovalent substitution of $\mathrm{Mg}^{2+}$ for $\mathrm{Fe}^{2+}, \mathrm{Al}^{3+}$ for $\mathrm{Cr}^{3+}, \mathrm{Al}^{3+}$ for $\mathrm{V}^{3+}$ and $\mathrm{Al}^{3+}$ for $\mathrm{Fe}^{3+}$, respectively (Table 9). 
It must be stressed that the difference between the ordered and disordered formula being considered for oxy-dravite wholly relates $\mathrm{Mg}$-Al order-disorder and does not impact on the resulting chemical composition. The two atoms of $\mathrm{Mg}$ can be disordered over the $Y$ and $Z$ sites, or fully ordered at $\mathrm{Z}$ as occurs in the other $\operatorname{oxy}(\mathrm{O} 1)$-tourmalines such as oxy-chromiumdravite and oxy-vanadium-dravite (Table 9). In this regard, several empirical structural formulae of oxy-dravite reported in the literature approach $\mathrm{Na}^{\mathrm{Y}}\left(\mathrm{Al}_{2} \mathrm{Mg}\right)^{\mathrm{Z}}\left(\mathrm{Al}_{5} \mathrm{Mg}\right) \mathrm{Si}_{6} \mathrm{O}_{18}\left(\mathrm{BO}_{3}\right)_{3}(\mathrm{OH})_{3} \mathrm{O}$ (e.g., Bloodaxe et al. 1999; Bosi and Lucchesi, 2004, 2007; Bosi et al. 2010) rather than the end-member proposed herein. The occurrence of $\mathrm{Mg}$ at the $\mathrm{Z}$ site and $\mathrm{Al}$ at the $Y$ site is commonly coupled to the occurrence of $\mathrm{O}^{2-}$ at the $\mathrm{O} 1$ site, controlled by the relationship $2^{\mathrm{Y}} \mathrm{Mg}^{2+}+{ }^{\mathrm{Z}} \mathrm{Al}^{3+}+{ }^{\mathrm{W}}(\mathrm{OH})^{1-} \leftrightarrow 2^{\mathrm{Y}} \mathrm{Al}^{3+}+{ }^{\mathrm{Z}} \mathrm{Mg}^{2+}+{ }^{\mathrm{W}} \mathrm{O}^{2-}$ (Hawthorne 1996). This relationship has been generalized as $3{ }^{\mathrm{Y}} \mathrm{Mg}^{2+}+2^{\mathrm{Z}} \mathrm{Al}^{3+}+{ }^{\mathrm{W}}(\mathrm{OH})^{1-} \leftrightarrow$ $3^{\mathrm{Y}} \mathrm{Al}^{3+}+2^{\mathrm{Z}} \mathrm{Mg}^{2+}+{ }^{\mathrm{W}} \mathrm{O}^{2-}$ by Henry et al. (2011) on the basis of findings of Bosi and Lucchesi (2007), namely that a maximum of 2 divalent cations (i.e., $\mathrm{Mg}^{2+}+\mathrm{Fe}^{2+}$ ) per formula unit can occur at the $Z$ site. The latter authors, however, based their findings on Al-poor tourmalines, in which the $\mathrm{Al}$ is substituted by ions with larger ionic radius (e.g., $\mathrm{Fe}^{3+}$ and $\mathrm{Cr}$ ). Actually, the amounts of $\mathrm{Mg}$ at $\mathrm{Z}$ are a product of the mismatch in size of cations occupying the Z-site; in fact, this mismatch is larger when involving $\mathrm{Mg}-\mathrm{Al}$ rather than $\mathrm{Mg}-\mathrm{Cr}^{3+}$ or $\mathrm{Mg}-\mathrm{V}^{3+}$ as the ionic radii of ${ }^{\mathrm{Z}} \mathrm{Cr}^{3+}(0.613 \AA)$ or ${ }^{\mathrm{Z}} \mathrm{V}^{3+}(0.653 \AA)$ are much larger than that of ${ }^{\mathrm{Z}} \mathrm{Al}(0.543 \AA)$ (Bosi and Lucchesi 2007). Figure 3 displays the increase of $\Sigma \mathrm{R}^{2+}$ at $Z$ (such as $\mathrm{Mg}$ and $\mathrm{Fe}^{2+}$ ) as a function of replacement of $\Sigma \mathrm{Al}$ at $Y$ and $Z$ by larger cations like $\mathrm{V}^{3+}, \mathrm{Cr}^{3+}$ and $\mathrm{Fe}^{3+}$ in tourmalines, showing that the amounts of $\mathrm{Mg}$ at the $Z$ site is dependent on the $\mathrm{R}^{3+}$-cation size. These observations strongly support the concept that $\mathrm{Mg}$ is distributed over the $Y$ and $Z$ sites in

312 Al-rich oxy(O1)-tourmalines. Note that although the occurrence of $\mathrm{Fe}^{2+}$ at $Z$ seems to be

313 limited to $\mathrm{Fe}^{3+}$-bearing Al-rich tourmalines (e.g., Filip et al 2012), $\mathrm{Mg}$ is observed as to be the 314 only divalent cation occurring at the $Z$ site in Al-poor tourmalines (e.g., Bosi et al 2004, 2012, 315 2013).

\section{CONCLUDING REMARKS}

Some important characteristics of oxy-dravite are:

1) the end-member formula is: $\mathrm{Na}^{\mathrm{Y}}\left(\mathrm{Al}_{3}\right)^{\mathrm{Z}}\left(\mathrm{Al}_{4} \mathrm{Mg}_{2}\right) \mathrm{Si}_{6} \mathrm{O}_{18}\left(\mathrm{BO}_{3}\right)_{3}(\mathrm{OH})_{3} \mathrm{O}$; 
This is a preprint, the final version is subject to change, of the American Mineralogist (MSA)

Cite as Authors (Year) Title. American Mineralogist, in press.

2) the most representative ideal formula is: $\mathrm{Na}^{\mathrm{Y}}\left(\mathrm{Al}_{2} \mathrm{Mg}\right)^{\mathrm{Z}}\left(\mathrm{Al}_{5} \mathrm{Mg}\right) \mathrm{Si}_{6} \mathrm{O}_{18}\left(\mathrm{BO}_{3}\right)_{3}(\mathrm{OH})_{3} \mathrm{O}$;

3) the $\mathrm{Mg}-\mathrm{Al}$ disorder over the $Y$ and $Z$ sites is controlled by the short-range bond-valence requirements of $\mathrm{O}^{2-}$ at $\mathrm{O} 1$;

4) the amount of $\mathrm{Mg}$ at the $Z$ site is a function of the degree of cation size mismatch at $\mathrm{Z}$.

\section{ACKNOWLEDGMENTS}

We thank Ulf Hålenius for his kind assistance in the collection and interpretation of optical absorption spectra. Chemical analyses were carried out with the kind assistance of $\mathrm{M}$. Serracino to whom the authors express their gratitude. We also thank the AE A. McDonald for his useful suggestions that improved the quality of the manuscript.

\section{REFERENCES CITED}

Agrosì, G., Bosi, F., Lucchesi, S., Melchiorre, G., and Scandale, E. (2006) Mn-tourmaline crystals from island of Elba (Italy): Growth history and growth marks. American Mineralogist, 91, 944-952.

Bačík, P., Cempírek, J., Uher, P., Novák, M., Ozdín, D., Filip, J., Škoda, R., Breiter, K., Klementová, M., and Duud'a R. (2013) Oxy-schorl, $\mathrm{Na}\left(\mathrm{Fe}^{2+}{ }_{2} \mathrm{Al}\right) \mathrm{Al}_{6} \mathrm{Si}_{6} \mathrm{O}_{18}\left(\mathrm{BO}_{3}\right)_{3}(\mathrm{OH})_{3} \mathrm{O}$, a new mineral from Zlatá Idka, Slovak Republic and Přibyslavice, Czech Republic. American Mineralogist. Doi.org/10.2138/am.2013.4293.

Bloodaxe, E.S., Hughes, J.M., Dyar, M.D., Grew, E.S., and Guidotti, C.V. (1999) Linking structure and chemistry in the schorl-dravite series. American Mineralogist, 84, 922.928.

Bosi, F. (2008) Disordering of $\mathrm{Fe}^{2+}$ over octahedrally coordinated sites of tourmaline. American Mineralogist, 93, 1647-1653.

Bosi, F. (2010) Octahedrally coordinated vacancies in tourmaline: a theoretical approach. Mineralogical Magazine, 74, 1037-1044.

Bosi, F. (2011) Stereochemical constraints in tourmaline: from a short-range to a long-range structure. Canadian Mineralogist, 49, 17-27.

Bosi, F. and Lucchesi, S. (2004) Crystal chemistry of the schorl-dravite series. European Journal of Mineralogy, 16, 335-344. 
Bosi, F. and Lucchesi, S. (2007) Crystal chemical relationships in the tourmaline group: structural constraints on chemical variability. American Mineralogist, 92, 1054-1063.

Bosi F., Lucchesi, S., and Reznitskii, L. (2004) Crystal chemistry of the dravite-chromdravite series. European Journal of Mineralogy, 16, 345-352.

Bosi, F., Balić-Žunić, T., and Surour, A.A. (2010) Crystal structure analysis of four tourmalines from the Cleopatra's Mines (Egypt) and Jabal Zalm (Saudi Arabia), and the role of $\mathrm{Al}$ in the tourmaline group. American Mineralogist, 95, 510-518.

Bosi, F., Reznitskii, L., and Skogby, H. (2012) Oxy-chromium-dravite, $\mathrm{NaCr}_{3}\left(\mathrm{Cr}_{4} \mathrm{Mg}_{2}\right)\left(\mathrm{Si}_{6} \mathrm{O}_{18}\right)\left(\mathrm{BO}_{3}\right)_{3}(\mathrm{OH})_{3} \mathrm{O}$, a new mineral species of the tourmaline supergroup. American Mineralogist, 97, 2024-2030.

Brown, I.D. and Altermatt, D. (1985) Bond-valence parameters obtained from a systematic analysis of the Inorganic Crystal Structure Database. Acta Crystallographica, B41, 244247.

Clark, C.M., Hawthorne, F.C., and Ottolini, L. (2011) Fluor-dravite, $\mathrm{NaMg}_{3} \mathrm{Al}_{6} \mathrm{Si}_{6} \mathrm{O}_{18}\left(\mathrm{BO}_{3}\right)_{3}(\mathrm{OH})_{3} \mathrm{~F}$, a new mineral species of the tourmaline group from the Crabtree emerald mine, Mitchell County, North Carolina: description and crystal structure.

Dunn, P.J., Arem, J.E. and Saul, J. (1975) Red dravite from Kenya. Journal of Gemmology, $14,386-387$.

Filip, J., Bosi, F., Novák, M., Skogby, H., Tuček, J., Čuda, J., and Wildner, M. (2012) Redox processes of iron in the tourmaline structure: example of the high-temperature treatment of $\mathrm{Fe}^{3+}$-rich schorl. Geochimica et Cosmochimica Acta, 86, 239-256.

Foit, F.F. Jr. (1989) Crystal chemistry of alkali-deficient schorl and tourmaline structural relationships. American Mineralogist, 74, 422-431.

Grice, J.D. and Ercit, T.S. (1993) Ordering of Fe and $\mathrm{Mg}$ in the tourmaline crystal structure:

Jernberg, P. and Sundqvist, T. (1983) A versatile Mössbauer analysis program. Uppsala University, Institute of Physics (UUIP-1090). spinel-galaxite solid solution. American Mineralogist, 96, 617-622. 
Hawthorne, F.C. (1996) Structural mechanisms for light-element variations in tourmaline. Canadian Mineralogist, 34, 123-132.

Hawthorne, F.C. (2002a) Bond-valence constraints on the chemical composition of tourmaline. Canadian Mineralogist, 40, 789-797.

Hawthorne, F.C. (2002b) The use of end-member charge-arrangements in defining new mineral species and heterovalent substitutions in complex minerals. Canadian Mineralogist, 40, 699-710.

Hawthorne, F.C. and Henry, D. (1999) Classification of the minerals of the tourmaline group. European Journal of Mineralogy, 11, 201-215.

Hawthorne, F.C., MacDonald, D.J., and Burns, P.C. (1993) Reassignment of cation occupancies in tourmaline: Al-Mg disorder in the crystal structure of dravite. American Mineralogist, 78, 265.270.

Henry, D.J. and Dutrow, B.L. (2011) The incorporation of fluorine in tourmaline: Internal crystallographic controls or external environmental influences? Canadian Mineralogist, $49,41-56$.

Henry, D.J., Novák, M., Hawthorne, F.C., Ertl, A., Dutrow, B., Uher, P., and Pezzotta, F. (2011) Nomenclature of the tourmaline supergroup minerals. American Mineralogist, 96, 895-913.

Holland, T.J.B. and Redfern, S.A.T. (1997) Unit cell refinement from powder diffraction data: the use of regression diagnostics. Mineralogical Magazine, 61, 65-77.

Lussier, A.J., Aguiar, P.M., Michaelis, V.K., Kroeker, S., Herwig, S., Abdu, Y., and Hawthorne, F.C. (2008) Mushroom elbaite from the Kat Chay mine, Momeik, near spectroscopy. Mineralogical Magazine, 72, 747-761.

Lussier, A.J., Hawthorne, F.C., Aguiar, P.M., Michaelis, V.K., and Kroeker, S. (2011a) Elbaite-liddicoatite from Black Rapids glacier, Alaska. Periodico di Mineralogia, 80, 5773.

Lussier, A.J., Abdu, Y. Hawthorne, F.C., Michaelis, V.K., Aguiar, P.M., and Kroeker, S. (2011b) Oscillatory zoned liddicoatite from Anjanabonoina, central Madagascar. I. Crystal chemistry and structure by SREF and ${ }^{11} \mathrm{~B}$ and ${ }^{27} \mathrm{Al}$ MAS NMR spectroscopy. Canadian Mineralogist, 49, 63-88.

Mandarino, J.A. (1976) The Gladstone-Dale relationship. Part I: derivation of new constants. Canadian Mineralogist, 14, 498-502. 
Mandarino, J.A. (1981) The Gladstone-Dale relationship. Part IV: the compatibility concept and its application. Canadian Mineralogist, 19, 441-450.

Mattson, S.M. and Rossman, G.R. (1984) Ferric iron in tourmaline. Physics and Chemistry of Minerals, 11, 225-234.

Novák, M., Povondra, P., and Selway, J.B. (2004) Schorl-oxy-schorl to dravite-oxy-dravite tourmaline from granitic pegmatites; examples from the Moldanubicum, Czech Republic. European Journal of Mineralogy, 16, 323-333.

Novák M., Škoda P., Filip J., Macek I., and Vaculovič T. (2011) Compositional trends in tourmaline from intragranitic NYF pegmatites of the Třebíč Pluton, Czech Republic; electron microprobe, Mössbauer and LA-ICP-MS study. Canadian Mineralogist, 49, 359-380.

Pouchou, J.L. and Pichoir, F. (1991) Quantitative analysis of homogeneous or stratified microvolumes applying the model "PAP." In K.F.J. Heinrich and D.E. Newbury, Eds., Electron probe quantitation, p. 31-75. Plenum, New York.

Razmanova, Z.P., Kornetova, V.A., Shipko, M.N., and Belov, N.B. (1983) Refinements in crystal structure and configuration of iron-bearing uvite. Trudy, Mineralogicheskiy Muzeya Akademiya Nauk SSSR, 31, 108-116 (in Russian)

Rozhdestvenskayaa, I.V., Setkovab, T.V., Vereshchagina, O.S., Shtukenberga, A.G., and Shapovalovb, Yu.B. (2012) Refinement of the Crystal Structures of Synthetic Nickeland Cobalt-Bearing Tourmalines. Crystallography Reports, 57, 57-63.

Sheldrick, G.M. (2008) A short history of SHELX. Acta Crystallographica, A64, 112-122.

Skogby, H., Bosi, F., and Lazor, P. (2012) Short-range order in tourmaline: a vibrational spectroscopic approach to elbaite. Physics and Chemistry of Minerals, 39, 811-816.

Taran, M.N. and Rossman, G.R. (2002) High-temperature, high-pressure optical spectroscopic study of ferric iron-bearing tourmaline. American Mineralogist, 87, 1148-1153.

Taylor, M.C., Cooper, M.A., and Hawthorne, F.C. (1995) Local charge-compensation in hydroxyl-deficient uvite. Canadian Mineralogist, 33, 1215.1221.

van Hinsberg, V.J. and Schumacher, J.C. (2011) Tourmaline as a petrogenetic indicator mineral in the Haut-Allier metamorphic suite, Massif Central, France. Canadian Mineralogist, 49, 177-194.

van Hinsberg, V.J., Henry, D.J., and Marschall, H.R. (2011) Tourmaline: an ideal indicator of its host environment. Canadian Mineralogist, 49, 1-16. 
453 Wright, S.E., Foley, J.A., and Hughes, J.M. (2000) Optimization of site occupancies in 454 minerals using quadratic programming. American Mineralogist, 85, 524-531.

455 Žàček, V., Frýda, J., Petrov, A., and Hyršl, J. (2000) Tourmalines of the povondraite456 (oxy)dravite series from the cap rock of meta-evaporite in Alto Chapare, Cochabamba, 457 Bolivia. Journal of the Czech Geological Society, 45, 3-12. 


\section{LIST OF TABLES}

461 TABLE 1. Single-crystal X-ray diffraction data details for oxy-dravite.

462 TABLE 2. Fractional atomic coordinates $(x, y, z)$ and site occupancies for oxy-dravite.

463 TABLE 3. Displacement parameters $\left(\AA^{2}\right)$ for oxy-dravite.

464 TABLE 4. Selected bond distances $(\AA)$ in oxy-dravite.

465 TABLE 5. X-ray powder diffraction data for oxy-dravite.

466 TABLE 5. Chemical composition of oxy-dravite.

467 TABLE 6. Site populations (apfu), site scattering factors (epfu) and mean bond distances ( $\AA$ )

468 for oxy-dravite.

469 TABLE 7. Bond valence calculations (valence unit) for oxy-dravite.

470 TABLE 8. Comparative data for oxy-dravite, fluor-dravite and dravite.

471 TABLE 9. Selected tourmaline formulae.

\section{LIST OF FIGURES AND FIGURE CAPTIONS}

FIGURE 1. Photos of the holotype fragment of oxy-dravite in reflected (a) and transmitted (b) light.

FIGURE 3. Room-temperature Mössbauer spectrum of oxy-dravite, fitted with two doublets (dotted lines) assigned to $\mathrm{Fe}^{3+}$ (centroid shift: $0.35 \mathrm{~mm} / \mathrm{s}$; quadrupole splittings: 0.76 and $1.60 \mathrm{~mm} / \mathrm{s}$ ), and one doublet (solid line) assigned to $\mathrm{Fe}^{2+}$ (centroid shift: $1.00 \mathrm{~mm} / \mathrm{s}$; quadrupole splitting: $2.43 \mathrm{~mm} / \mathrm{s}$, relative to $\alpha-\mathrm{Fe})$. The obtained $\mathrm{Fe}^{3+} / \Sigma \mathrm{Fe}$ area ratio is 0.96 , with an estimated error of \pm 0.02 . Thick line denotes summed spectrum.

Figure 3. Variation in $\Sigma \mathrm{Al}$ at $Y$ and $Z$ as a function of $\Sigma \mathrm{R}^{2+}$-cations $\left(\mathrm{Mg}, \mathrm{Fe}^{2+}, \mathrm{Co}, \mathrm{Ni}\right)$ at $Z$. The green arrow represents the substitution $\left(\mathrm{Cr}+\mathrm{V}^{3+}+\mathrm{Fe}^{3+}\right) \rightarrow \mathrm{Al}$, the red arrow represents the substitution $2^{\mathrm{Y}} \mathrm{Al}^{3+}+{ }^{\mathrm{Z}} \mathrm{Mg}^{2+}+{ }^{\mathrm{W}} \mathrm{O}^{2-} \rightarrow 2^{\mathrm{Y}} \mathrm{Mg}^{2+}+{ }^{\mathrm{Z}} \mathrm{Al}^{3+}+{ }^{\mathrm{W}}(\mathrm{OH})^{1-}$. Red circle represents the oxy-dravite from the present study. Filled circles represent 139 samples: uvite from Razmanova et al. (1983), 129 tourmalines of different compositions from the dataset of Bosi and Lucchesi (2007), dravite from Bosi (2008), 2 oxy-dravite samples plus 2 dravite samples from Bosi et al. (2010), oxy-chromium-dravite from Bosi et al. (2012), oxy-vanadium-dravite from Bosi et 
al. (2013), 2 oxy-schorl samples from Bačík et al. (2013). Black crosses represent squares represent the ideal dravite, ideal oxy-dravite with ordered (O-) and disordered (D-) formula (see text). 
Table 1. Single-crystal X-ray diffraction data details for oxy-dravite

Crystal sizes $(\mathrm{mm})$

a $(\AA)$

$c(\AA)$

$V\left(\AA^{3}\right)$

Range for data collection, $2 \theta\left(^{\circ}\right)$

Reciprocal space range $h k l$

Total number of frames

Set of measured reflections

Unique reflections, $R_{\text {int }}(\%)$

Completeness (\%)

Redundancy

Absorption correction method

Refinement method

Structural refinement program

Extinction coefficient

Flack parameter

wR2 (\%)

$R 1(\%)$ all data

$R 1(\%)$ for $I>2 \sigma(I)$

GooF

Largest diff. peak and hole $\left( \pm \mathrm{e}^{-} / \AA^{3}\right)$
$0.20 \times 0.25 \times 0.30$

$15.9273(2)$

7.2001(1)

$1581.81(4)$

$5-69$

$-22 \leq h \leq 25$

$-25 \leq k \leq 25$

$-11 \leq l \leq 11$

3265

7124

$1586,1.42$

99.9

9

\section{SADABS}

Full-matrix last-squares on $F^{2}$

SHELXL-97

$0.0046(2)$

$0.03(3)$

3.33

1.17

1.16

1.140

0.26 and -0.28

Notes: $R_{\text {int }}=$ merging residual value; $R 1=$ discrepancy index, calculated from $F$-data; $w R 2$

$=$ weighted discrepancy index, calculated from $F^{2}$-data; GooF = goodness of fit; Diff. Peaks $=$ maximum and minimum residual electron density. Radiation, MoKa $=0.71073 \AA$. Data collection temperature $=293 \mathrm{~K}$. Space group $R 3 m ; Z=3$. 
TABLE 2. Fractional atom coordinates and site occupancy for oxy-dravite $\left(\AA^{2}\right)$.

\begin{tabular}{clllc}
\hline Site & \multicolumn{1}{c}{$x / a$} & \multicolumn{1}{c}{$y / b$} & \multicolumn{1}{c}{$z / c$} & Site occupancy \\
\hline$X$ & 0 & 0 & $0.22939(18)$ & $\mathrm{Na}_{0.914(5)}$ \\
$Y$ & $0.12223(2)$ & $0.061116(11)$ & $0.63657(5)$ & $\mathrm{Al}_{0.826(2)} \mathrm{Fe}_{0.174(2)}$ \\
$Z$ & $0.297683(16)$ & $0.261493(17)$ & $0.61014(4)$ & $\mathrm{Al}_{1.00}$ \\
$B$ & $0.10989(4)$ & $0.21978(8)$ & $0.45430(16)$ & $\mathrm{B}_{1.00}$ \\
$T$ & $0.191532(13)$ & $0.189631(14)$ & 0 & $\mathrm{Si}_{1.00}$ \\
O1 & 0 & 0 & $0.7698(2)$ & $\mathrm{O}_{1.00}$ \\
O2 & $0.06076(3)$ & $0.12151(6)$ & $0.48724(12)$ & $\mathrm{O}_{1.00}$ \\
O3 & $0.26112(7)$ & $0.13056(4)$ & $0.50994(12)$ & $\mathrm{O}_{1.00}$ \\
O4 & $0.09356(3)$ & $0.18712(6)$ & $0.07152(12)$ & $\mathrm{O}_{1.00}$ \\
O5 & $0.18445(6)$ & $0.09223(3)$ & $0.09252(12)$ & $\mathrm{O}_{1.00}$ \\
O6 & $0.19447(4)$ & $0.18433(4)$ & $0.77729(9)$ & $\mathrm{O}_{1.00}$ \\
O7 & $0.28509(4)$ & $0.28474(4)$ & $0.07754(8)$ & $\mathrm{O}_{1.00}$ \\
O8 & $0.20920(4)$ & $0.27005(4)$ & $0.43936(9)$ & $\mathrm{O}_{1.00}$ \\
H3 & $0.2453(15)$ & $0.1227(7)$ & $0.396(3)$ & $\mathrm{H}_{1.00}$
\end{tabular}


This is a preprint, the final version is subject to change, of the American Mineralogist (MSA)

Cite as Authors (Year) Title. American Mineralogist, in press.

(DOI will not work until issue is live.) DOI: http://dx.doi.org/10.2138/am.2014.4441

TABLE 3. Displacement parameters $\left(\AA^{2}\right)$ for oxy-dravite

\begin{tabular}{clllllll}
\hline Site & $U^{11}$ & $U^{22}$ & $U^{33}$ & $U^{23}$ & $U^{13}$ & $U^{12}$ & $U_{\text {eq }} / U_{\text {iso }}{ }^{*}$ \\
\hline$X$ & $0.0217(4)$ & $0.0217(4)$ & $0.0235(6)$ & 0 & 0 & $0.0108(2)$ & $0.0223(3)$ \\
$Y$ & $0.00895(14)$ & $0.00675(11)$ & $0.01145(14)$ & $-0.00158(4)$ & $-0.00316(8)$ & $0.00448(7)$ & $0.00881(9)$ \\
$Z$ & $0.00531(9)$ & $0.00536(9)$ & $0.00583(9)$ & $0.00039(7)$ & $-0.00008(7)$ & $0.00262(7)$ & $0.00552(5)$ \\
$B$ & $0.0054(3)$ & $0.0060(4)$ & $0.0076(4)$ & $0.0005(3)$ & $0.00027(16)$ & $0.0030(2)$ & $0.00626(17)$ \\
$T$ & $0.00458(8)$ & $0.00429(8)$ & $0.00590(8)$ & $-0.00061(6)$ & $-0.00054(6)$ & $0.00226(6)$ & $0.00490(5)$ \\
O1 & $0.0127(4)$ & $0.0127(4)$ & $0.0075(6)$ & 0 & 0 & $0.00637(19)$ & $0.0110(2)$ \\
O2 & $0.0112(3)$ & $0.0042(3)$ & $0.0098(4)$ & $0.0009(2)$ & $0.00044(12)$ & $0.00210(15)$ & $0.00918(15)$ \\
O3 & $0.0221(4)$ & $0.0124(2)$ & $0.0049(3)$ & $0.00040(14)$ & $0.0008(3)$ & $0.0110(2)$ & $0.01206(15)$ \\
O4 & $0.0070(2)$ & $0.0140(4)$ & $0.0094(3)$ & $-0.0015(3)$ & $-0.00075(13)$ & $0.00699(18)$ & $0.00936(14)$ \\
O5 & $0.0148(4)$ & $0.0066(2)$ & $0.0083(3)$ & $0.00080(13)$ & $0.0016(3)$ & $0.00740(18)$ & $0.00900(13)$ \\
O6 & $0.0090(2)$ & $0.0089(2)$ & $0.0054(2)$ & $-0.00140(16)$ & $-0.00081(16)$ & $0.00505(18)$ & $0.00751(10)$ \\
O7 & $0.0064(2)$ & $0.0053(2)$ & $0.0084(2)$ & $-0.00106(17)$ & $-0.00179(18)$ & $0.00047(17)$ & $0.00776(9)$ \\
O8 & $0.0039(2)$ & $0.0088(2)$ & $0.0140(2)$ & $0.00227(18)$ & $0.00051(18)$ & $0.00275(19)$ & $0.00909(10)$ \\
H3 & & & & & & & $0.018^{*}$ \\
\hline
\end{tabular}

Notes: Equivalent $\left(U_{\text {eq }}\right)$ and isotropic $\left(U_{\text {iso }}\right)$ displacement parameters; $\mathrm{H}$-atom was constrained to have a $U_{\text {iso }} 1.5$ times the $U_{\text {eq }}$ value of the $\mathrm{O} 3$ oxygen. 
TABLE 4. Selected bond distances $(\AA)$ for oxy-dravite.

\begin{tabular}{|c|c|c|c|}
\hline$B-\mathrm{O} 2$ & $1.3760(14)$ & $Y-01$ & $1.9397(8)$ \\
\hline$B-O 8^{A}(\times 2)$ & $1.3740(8)$ & $Y-O 2^{\mathrm{B}}(\times 2)$ & $1.9955(6)$ \\
\hline \multirow[t]{2}{*}{$<B-O>$} & 1.375 & $Y-03$ & $2.1216(10)$ \\
\hline & & $Y-\mathrm{O}^{\mathrm{C}}(\times 2)$ & $1.9858(6)$ \\
\hline $\mathrm{T}-\mathrm{O} 4$ & $1.6246(3)$ & $<Y-O>$ & 2.004 \\
\hline T-O5 & $1.6396(4)$ & & \\
\hline$T-07$ & $1.6030(6)$ & Z-O3 & $1.9985(5)$ \\
\hline$T^{*}-\mathrm{O} 6$ & $1.6077(6)$ & Z-O6 & $1.9082(6)$ \\
\hline \multirow[t]{2}{*}{$<T-O>$} & 1.619 & $Z-O 8^{E}$ & $1.8993(6)$ \\
\hline & & $Z-O 7^{E}$ & $1.9073(6)$ \\
\hline$X-\mathrm{O} 2^{\mathrm{B}, \mathrm{F}}(\times 3)$ & $2.5012(12)$ & $\mathrm{Z}-\mathrm{O} 7^{\mathrm{D}}$ & $1.9572(6)$ \\
\hline$X-\mathrm{O} 4^{\mathrm{B}, \mathrm{F}}(\times 3)$ & $2.8201(10)$ & Z-O8 & $1.9258(6)$ \\
\hline$X-\mathrm{O}^{\mathrm{B}, \mathrm{F}}(\times 3)$ & $2.7284(10)$ & $<Z-O>$ & 1.933 \\
\hline \multirow[t]{2}{*}{$<X-O>$} & 2.683 & & \\
\hline & & $\mathrm{O} 3-\mathrm{H}$ & $0.85(2)$ \\
\hline
\end{tabular}

Notes: Standard uncertainty in parentheses. Superscript letters: $A=(y-x$, $y, z) ; \mathrm{B}=(y-x,-x, z) ; \mathrm{C}=(x, x-y, z) ; \mathrm{D}=(y-x+1 / 3,-x+2 / 3, z+$ $2 / 3) ; E=(-y+2 / 3, x-y+1 / 3, z+1 / 3) ; F=(-y, x-y, z)$. Transformations relate coordinates to those of Table 2 .

* Positioned in adjacent unit cell. 
TABLE 5. X-ray powder diffraction data for oxy-dravite

\begin{tabular}{|c|c|c|c|c|c|}
\hline$I_{\text {(meas) }}(\%)$ & $d_{\text {(meas) }}(\AA)$ & $d_{(\text {cal })}(\AA)$ & $h$ & $k$ & I \\
\hline 44 & 6.377 & 6.383 & 1 & 0 & 1 \\
\hline 25 & 4.978 & 4.979 & 0 & 2 & 1 \\
\hline 14 & 4.598 & 4.595 & 3 & 0 & 0 \\
\hline 67 & 4.222 & 4.221 & 2 & 1 & 1 \\
\hline 64 & 3.983 & 3.980 & 2 & 2 & 0 \\
\hline 84 & 3.483 & 3.484 & 0 & 1 & 2 \\
\hline 10 & 3.379 & 3.377 & 1 & 3 & 1 \\
\hline 9 & 3.011 & 3.008 & 4 & 1 & 0 \\
\hline 100 & 2.963 & 2.962 & 1 & 2 & 2 \\
\hline 7 & 2.898 & 2.896 & 3 & 2 & 1 \\
\hline 7 & 2.622 & 2.621 & 3 & 1 & 2 \\
\hline 68 & 2.576 & 2.575 & 0 & 5 & 1 \\
\hline 19 & 2.400 & 2.400 & 0 & 0 & 3 \\
\hline 14 & 2.377 & 2.376 & 2 & 3 & 2 \\
\hline 14 & 2.343 & 2.342 & 5 & 1 & 1 \\
\hline 8 & 2.190 & 2.189 & 5 & 0 & 2 \\
\hline 9 & 2.163 & 2.162 & 4 & 3 & 1 \\
\hline 13 & 2.128 & 2.128 & 0 & 3 & 3 \\
\hline 15 & 2.056 & 2.055 & 2 & 2 & 3 \\
\hline 35 & 2.041 & 2.040 & 1 & 5 & 2 \\
\hline 6 & 2.019 & 2.018 & 1 & 6 & 1 \\
\hline 52 & 1.915 & 1.918 & 3 & 4 & 2 \\
\hline 7 & 1.876 & 1.876 & 1 & 4 & 3 \\
\hline 6 & 1.849 & 1.848 & 6 & 2 & 1 \\
\hline 5 & 1.785 & 1.785 & 1 & 0 & 4 \\
\hline 18 & 1.660 & 1.660 & 0 & 6 & 3 \\
\hline 25 & 1.633 & 1.640 & 2 & 7 & 1 \\
\hline 11 & 1.593 & 1.592 & 5 & 5 & 0 \\
\hline 2 & 1.528 & 1.532 & 9 & 0 & 0 \\
\hline 14 & 1.507 & 1.507 & 0 & 5 & 4 \\
\hline 8 & 1.504 & 1.504 & 8 & 2 & 0 \\
\hline 4 & 1.481 & 1.481 & 2 & 4 & 4 \\
\hline 14 & 1.456 & 1.456 & 5 & 1 & 4 \\
\hline 6 & 1.432 & 1.430 & 7 & 4 & 0 \\
\hline 6 & 1.418 & 1.417 & 6 & 5 & 1 \\
\hline 11 & 1.410 & 1.410 & 4 & 3 & 4 \\
\hline 6 & 1.329 & 1.329 & 3 & 5 & 4 \\
\hline 5 & 1.310 & 1.309 & 10 & 1 & 0 \\
\hline 9 & 1.276 & 1.277 & 5 & 0 & 5 \\
\hline
\end{tabular}


TABLE 6. Chemical composition of oxy-dravite

\begin{tabular}{llll}
\hline & Weight \% & & Apfu \\
\hline $\mathrm{SiO}_{2}$ & $37.01(10)$ & $\mathrm{Si}$ & $5.98(5)$ \\
$\mathrm{TiO}_{2}$ & $0.14(3)$ & $\mathrm{Ti}^{4+}$ & $0.017(4)$ \\
$\mathrm{B}_{2} \mathrm{O}_{3}{ }^{*}$ & 10.76 & $\mathrm{~B}$ & 3.00 \\
$\mathrm{Al}_{2} \mathrm{O}_{3}$ & $33.11(20)$ & $\mathrm{Al}$ & $6.31(5)$ \\
$\mathrm{Fe}_{2} \mathrm{O}_{3}{ }^{\dagger}$ & 5.00 & $\mathrm{Fe}^{3+}$ & $0.61(1)$ \\
$\mathrm{FeO}^{\dagger}$ & 0.19 & $\mathrm{Fe}^{2+}$ & $0.025(3)$ \\
$\mathrm{MgO}^{+}$ & $8.56(8)$ & $\mathrm{Mg}$ & $2.06(2)$ \\
$\mathrm{Na}_{2} \mathrm{O}$ & $2.65(3)$ & $\mathrm{Na}$ & $0.83(1)$ \\
$\mathrm{K}_{2} \mathrm{O}$ & $0.10(1)$ & $\mathrm{K}$ & $0.021(1)$ \\
$\mathrm{H}_{2} \mathrm{O}^{*}$ & 2.65 & $\mathrm{OH}$ & 3.24 \\
& & & \\
Total & 100.58 & & \\
\hline
\end{tabular}

Notes: number of ions calculated on basis of $31(\mathrm{O}, \mathrm{OH}, \mathrm{F})$. Uncertainties for oxides (in brackets) are standard deviation of 10 spots. $\mathrm{B}_{2} \mathrm{O}_{3}$ and $\mathrm{H}_{2} \mathrm{O}$ uncertainty assumed at $5 \%$. Standard uncertainty for ions was calculated by error-propagation theory.

* Calculated by stoichiometry.

† Determined by Mössbauer spectroscopy, $(\mathrm{FeO})_{\mathrm{EMPA}}=4.69(9)$. 
TABLE 7. Site populations (apfu), site scattering factors (epfu) and mean bond lengths $(\AA)$ for oxy-dravite

\begin{tabular}{|c|c|c|c|c|c|}
\hline \multirow{2}{*}{ Site } & \multirow{2}{*}{ Site population } & \multicolumn{2}{|c|}{ Site scattering } & \multicolumn{2}{|c|}{ Mean bond length } \\
\hline & & refined & calculated & refined & calculated $^{*}$ \\
\hline$x$ & $0.83 \mathrm{Na}+0.02 \mathrm{~K}+0.15 \square$ & $10.05(5)$ & 9.53 & & \\
\hline Y & $\begin{array}{l}1.34 \mathrm{Al}+1.03 \mathrm{Mg}+0.58 \mathrm{Fe}^{3+}+0.03 \mathrm{Fe}^{2+}+0.02 \mathrm{Ti} \\
\left(1.20 \mathrm{Al}+1.16 \mathrm{Mg}+0.60 \mathrm{Fe}^{3+}+0.03 \mathrm{Fe}^{2+}+0.02 \mathrm{Ti}^{* *}\right.\end{array}$ & $45.8(1)$ & 46.0 & 2.004 & 2.002 \\
\hline$Z$ & $\begin{array}{l}4.94 \mathrm{Al}+1.03 \mathrm{Mg}+0.02 \mathrm{Fe}^{3+} \\
(5.11 \mathrm{Al}+0.90 \mathrm{Mg})^{\star *}\end{array}$ & $78^{\dagger}$ & 77.3 & 1.933 & 1.931 \\
\hline$T$ & $\begin{array}{l}5.98 \mathrm{Si}+0.02 \mathrm{Al} \\
(6.00 \mathrm{Si})^{\star *}\end{array}$ & $84^{\dagger}$ & 84 & 1.619 & 1.619 \\
\hline$B$ & $3.00 \mathrm{~B}$ & $15^{\dagger}$ & 15 & 1.375 & 1.374 \\
\hline $\mathrm{O} 3$ & $3.00(\mathrm{OH})$ & $24^{\dagger}$ & 24 & & \\
\hline 01 & $0.76 \mathrm{O}+0.24(\mathrm{OH})$ & $9^{\dagger}$ & 9 & & \\
\hline
\end{tabular}

Notes: $\mathrm{O} 2, \mathrm{O} 4 \ldots \mathrm{O} 8$ sites are fully populated by $\mathrm{O}^{2-}$; apfu = atoms per formula unit; epfu = electrons per formula unit.

* Calculated from the ionic radii (Bosi and Lucchesi 2007).

** Site populations optimized by the procedure of Wright et al. (2000).

${ }^{\dagger}$ Fixed in the final stages of refinement. 
TABLE 8. Bond valence calculations (valence unit) for oxy-dravite

\begin{tabular}{ccccccc}
\hline Site & $X$ & $Y$ & $Z$ & $T$ & $B$ & BVS \\
\hline O1 & & $0.51^{\times 3} \rightarrow$ & & & & 1.53 \\
O2 & $0.15^{\times 3} \downarrow$ & $\begin{array}{c}0.44^{\times 2} \downarrow \rightarrow \\
\text { O3 }\end{array}$ & & & 0.99 & 2.01 \\
O4 & $0.07^{\times 3} \downarrow$ & & $0.40^{\times 2} \rightarrow$ & & & 1.11 \\
O5 & $0.08^{\times 3} \downarrow$ & & & $1.00^{\times 2} \rightarrow$ & & 2.06 \\
O6 & & $0.45^{\times 2} \downarrow$ & 0.51 & 1.04 & & 2.00 \\
O7 & & & 0.51 & 1.06 & & 2.00 \\
& & & 0.45 & & & \\
O8 & & & 0.49 & & $0.99^{\times 2} \downarrow$ & 2.00 \\
& & & 0.52 & & & \\
BVS & 0.91 & 2.59 & 2.87 & 4.06 & 2.97 & \\
MFV & 0.85 & 2.65 & 2.83 & 4.00 & 3.00 & \\
\hline
\end{tabular}

${ }^{*} \mathrm{MFV}=$ mean formal valence from site populations 
This is a preprint, the final version is subject to change, of the American Mineralogist (MSA)

Cite as Authors (Year) Title. American Mineralogist, in press.

(DOI will not work until issue is live.) DOI: http://dx.doi.org/10.2138/am.2014.4441

TABLE 9. Comparative data for oxy-dravite, fluor-dravite and dravite.

\begin{tabular}{|c|c|c|c|}
\hline & $\begin{array}{c}\text { Oxy-dravite } \\
\mathrm{Na}\left(\mathrm{Al}_{2} \mathrm{Mg}\right)\left(\mathrm{Al}_{5} \mathrm{Mg}\right) \mathrm{Si}_{6} \mathrm{O}_{18}\left(\mathrm{BO}_{3}\right)_{3}(\mathrm{OH})_{3} \mathrm{O}\end{array}$ & $\begin{array}{c}\text { Fluor-dravite } \\
\mathrm{NaMg}_{3} \mathrm{Al}_{6} \mathrm{Si}_{6} \mathrm{O}_{18}\left(\mathrm{BO}_{3}\right)_{3}(\mathrm{OH})_{3} \mathrm{~F}\end{array}$ & $\begin{array}{c}\text { Dravite } \\
\mathrm{NaMg}_{3} \mathrm{Al}_{6} \mathrm{Si}_{6} \mathrm{O}_{18}\left(\mathrm{BO}_{3}\right)_{3}(\mathrm{OH})_{3}(\mathrm{OH})\end{array}$ \\
\hline$a(\AA)$ & $15.9273(2)$ & $15.955(3)$ & $15.96(2)$ \\
\hline$c(\AA)$ & $7.2001(1)$ & $7.153(2)$ & $7.21(2)$ \\
\hline$V\left(\AA^{3}\right)$ & $1581.81(4)$ & $1576.9(6)$ & 1590.5 \\
\hline Space group & $R 3 m$ & $R 3 m$ & $R 3 m$ \\
\hline Optic sign & Uniaxial (-) & Uniaxial (-) & Uniaxial (-) \\
\hline$\omega$ & $1.650(5)$ & $1.645(2)$ & $1.634-1.661$ \\
\hline$\varepsilon$ & $1.620(5)$ & $1.621(2)$ & $1.612-1.632$ \\
\hline Colour & Dark red & Blackish brown & $\begin{array}{l}\text { Pale brown to dark-brown to } \\
\text { brownish-black, dark-yellow, blue }\end{array}$ \\
\hline Pleochroism & $\begin{array}{l}O=\text { orange } \\
E=\text { pink }\end{array}$ & $\begin{array}{c}\mathrm{O}=\text { pale yellow-brown } \\
\mathrm{E}=\text { colorless }\end{array}$ & $\begin{array}{c}\mathrm{O}=\text { pale yellow } \\
\mathrm{E}=\text { colorless, yellowish, greenish, } \\
\text { brownish }\end{array}$ \\
\hline Reference & This work & Clark et al. (2011) & www.mindat.org \\
\hline
\end{tabular}


TABLE 10. Selected tourmaline formulae.

\begin{tabular}{ccc}
\hline Name & Representative formula & $\begin{array}{c}\text { Substitution related to } \\
\text { oxy-dravite }\end{array}$ \\
\hline Oxy-dravite & $\mathrm{Na}^{\mathrm{Y}}\left(\mathrm{Al}_{2} \mathrm{Mg}\right)^{\mathrm{Z}}\left(\mathrm{Al}_{5} \mathrm{Mg}\right) \mathrm{Si}_{6} \mathrm{O}_{18}\left(\mathrm{BO}_{3}\right)_{3}(\mathrm{OH})_{3} \mathrm{O}$ & \\
Oxy-schorl & $\mathrm{Na}^{\mathrm{Y}}\left(\mathrm{AlFe}^{2+}{ }_{2}\right)^{\mathrm{Z}}\left(\mathrm{Al}_{6}\right) \mathrm{Si}_{6} \mathrm{O}_{18}\left(\mathrm{BO}_{3}\right)_{3}(\mathrm{OH})_{3} \mathrm{O}$ & $\mathrm{Fe}^{2+} \rightarrow \mathrm{Mg}^{2+}$ \\
Oxy-chromium-dravite & $\mathrm{Na}^{\mathrm{Y}}\left(\mathrm{Cr}_{3}\right)^{\mathrm{Z}}\left(\mathrm{Cr}_{4} \mathrm{Mg}_{2}\right) \mathrm{Si}_{6} \mathrm{O}_{18}\left(\mathrm{BO}_{3}\right)_{3}(\mathrm{OH})_{3} \mathrm{O}$ & $\mathrm{Cr}^{3+} \rightarrow \mathrm{Al}^{3+}$ \\
Oxy-vanadium-dravite & $\mathrm{Na}^{\mathrm{Y}}\left(\mathrm{V}_{3}\right)^{\mathrm{Z}}\left(\mathrm{V}_{4} \mathrm{Mg}_{2}\right) \mathrm{Si}_{6} \mathrm{O}_{18}\left(\mathrm{BO}_{3}\right)_{3}(\mathrm{OH})_{3} \mathrm{O}$ & $\mathrm{V}^{3+} \rightarrow \mathrm{Al}^{3+}$ \\
Povondravite & $\mathrm{Na}^{\mathrm{Y}}\left(\mathrm{Fe}^{3+}{ }^{3}\right)^{\mathrm{Z}}\left(\mathrm{Fe}^{3+}{ }_{4} \mathrm{Mg}_{2}\right) \mathrm{Si}_{6} \mathrm{O}_{18}\left(\mathrm{BO}_{3}\right)_{3}(\mathrm{OH})_{3} \mathrm{O}$ & $\mathrm{Fe}^{3+} \rightarrow \mathrm{Al}^{3+}$ \\
\hline
\end{tabular}


This is a preprint, the final version is subject to change, of the American Mineralogist (MSA) Cite as Authors (Year) Title. American Mineralogist, in press.

(DOI will not work until issue is live.) DOI: http://dx.doi.org/10.2138/am.2014.4441

Figure 1a

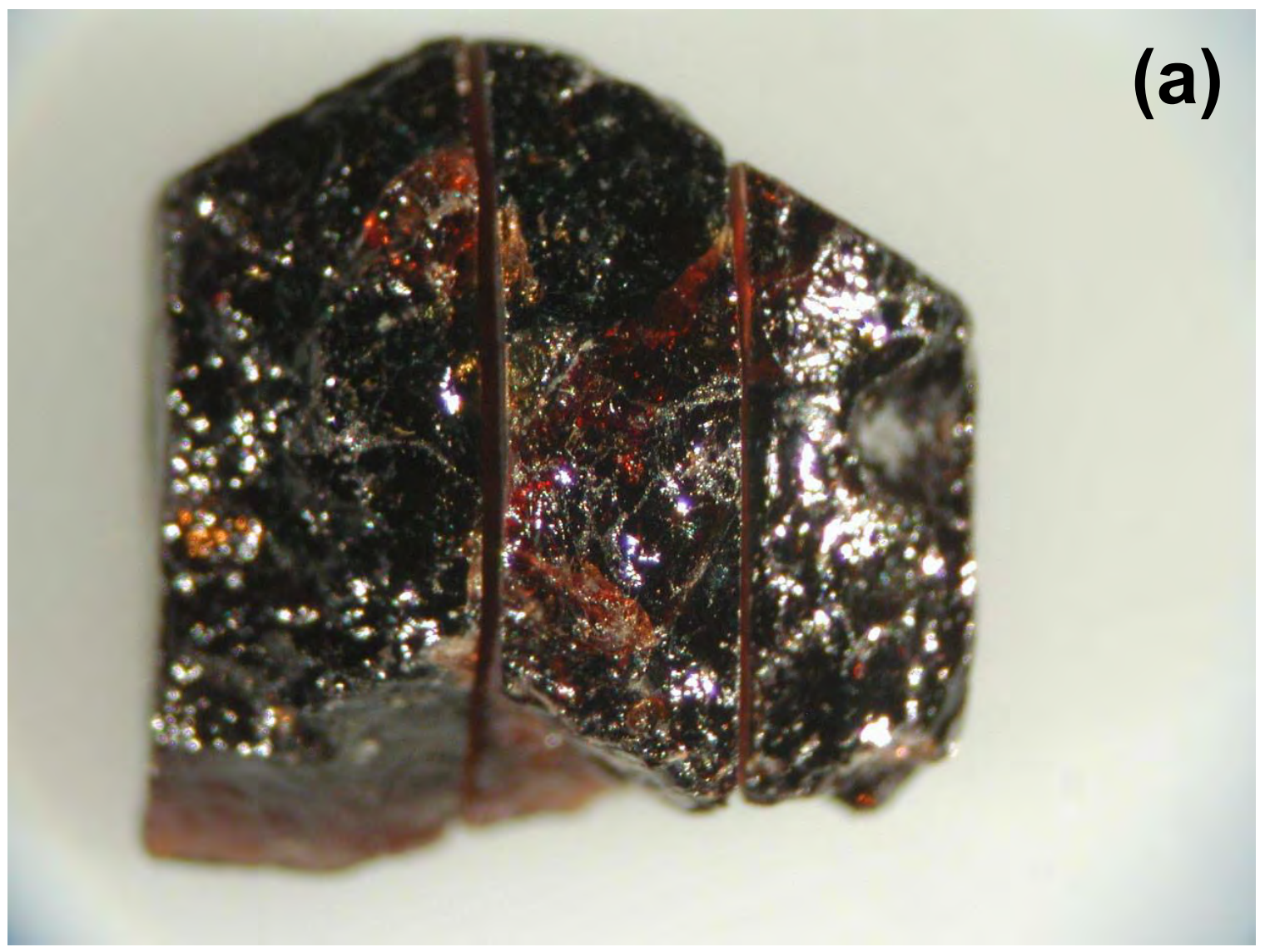




\section{Figure $1 b$}

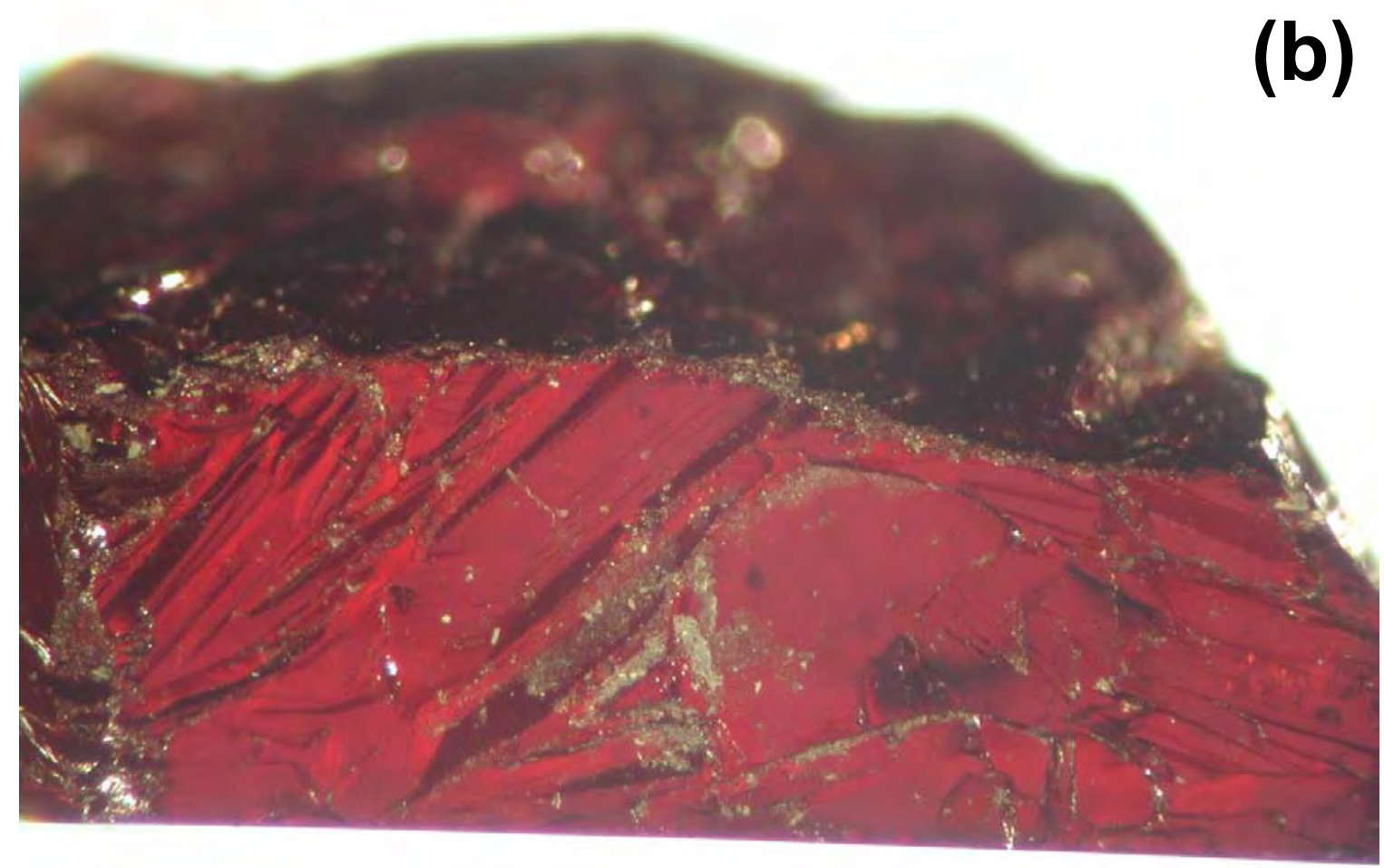


Figure 2

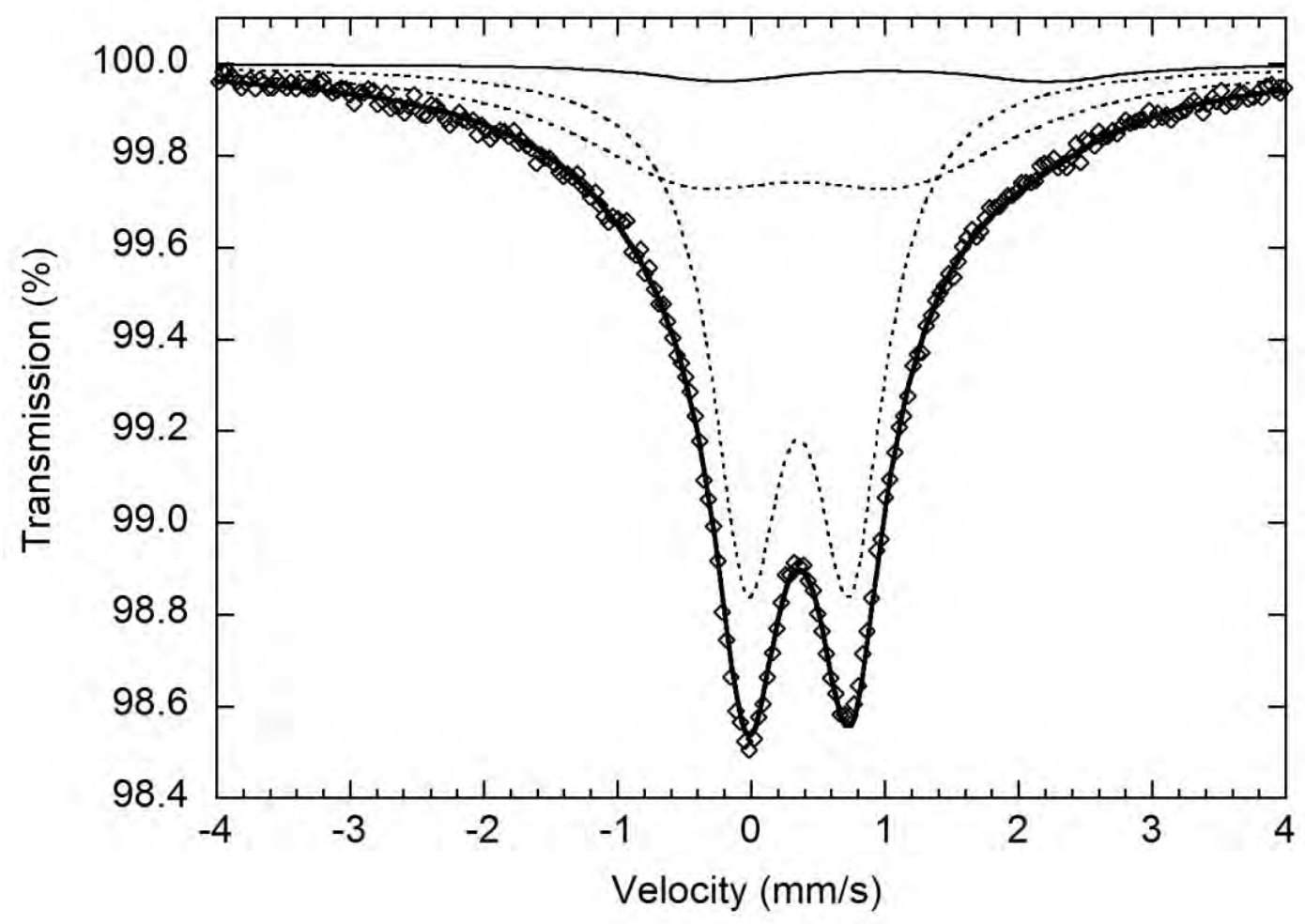




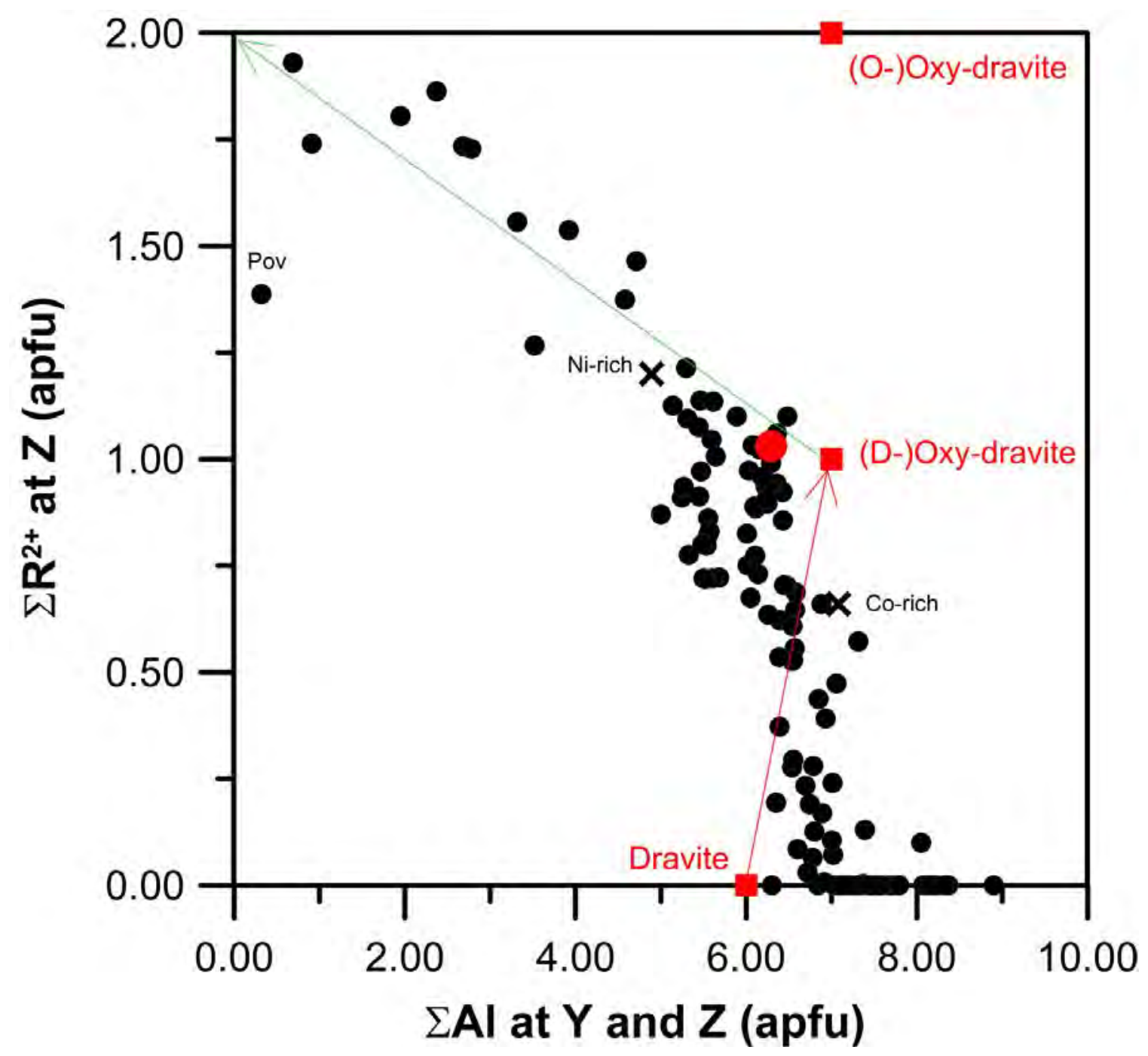

